\title{
Thromboprophylaxis in Elderly Surgical Patients: Current State and Future Considerations
}

\author{
Christina Delimpalta ${ }^{1}$, Luca Ponchietti ${ }^{2}$ \\ 'James Paget University Hospital NHS Trust, Gorleston, UK \\ ${ }^{2}$ Torrevieja University Hospital, Torrevieja (Alicante), Spain
}

Corresponding author:

Christina Delimpalta, MD

55F All Saints Green

Norwich, Norfolk, NR1 3LY

E-mail: christinadelimpalta@gmail.com

\section{Rezumat \\ Tromboprofilaxia la pacienții vârstnici: statusul actual și considerații pentru viitor}

Tromboembolismul venos reprezintã cea mai frecventã cauzã evitabilã de deces în rândul pacienților spitalizați. Pacienții vârstnici care suferã intervenții operatorii în sfera Chirurgiei Generale prezintã o susceptibilitate crescutã pentru Tromboza Venoasã Profundã /Tromboembolism Pulmonar Acut (TVP/TEPA). Riscul de TVP/TEPA creşte de altfel adițional în prezența comorbiditãților prevalente în grupul pacienților vârstnici. $\mathrm{Cu}$ toate acestea, TVP/TEPA este de multe ori subdiagnosticat şi subtratat în acest grup de pacienți. În prezent existã o serie de scoruri de risc clinice care clasificã pacienții în categorii de risc scãzut/moderat/crescut pentru TVP/TEPA. Ghidurile clinice de bunã practicã pentru tromboprofilaxie propun fie o combinație de procedee mecanice (ciorapi elastici sau compresie gambiera penumaticã intermitentã), fie agenți farmacologici (ex. Heparina cu greutate molecularã redusã sau anticoagulante orale). Dat fiind faptul cã riscul de sângerare ca efect secundar al tratamentului reprezintã o cauzã semnificativã de îngrijorare în ceea ce priveşte populația vârstnicã, metodele de tromboprofilaxie trebuie ajustate astfel încât acest risc sa fie cât mai scãzut. Atât opțiunea pentru un anumit tromboprofilactic, cât şi doza acestuia pot fi, de asemenea, influențate de o alterare a funcției renale. Durata necesarã tromboprofilaxiei este încã neclarã, ea putând varia între c. o sãptãmânã şi o lunã, în funcție de patologia pacientului şi evaluarea riscului individual de TVP/TEPA.

Cuvinte cheie: tromboembolism venos, pacienți geriatrici/varstnici, tromboprofilaxie 


\begin{abstract}
Venous thromboembolism is the number one cause of preventable death for hospital inpatients. Aging general surgical patients are especially susceptible to DVT/PE and this risk increases in the presence of other comorbidities prevalent in the elderly. However, it is often unrecognised and undertreated. Various risk scores classify patients in low, moderate and high risk categories. Current guidelines for thromboprophylaxis advocate combination of mechanical methods in the form of elastic stockings or intermittent pneumatic leg compression and pharmacological agents such as low molecular weight heparins and oral anticoagulants. Increased bleeding risk is a concern in this population and the method of prophylaxis needs to be adjusted as a result. Decreased renal function also influences the choice and dosage of medication. The required duration of prophylaxis is unclear but can range from one week to more than a month depending on the underlying pathology and individual risk assessment.
\end{abstract}

Key words: venous thromboembolism, elderly, thromboprophylaxis

\section{Introduction}

Each year, approximately 1,000,000 Americans suffer a venous thromboembolic (VTE) eventdeep vein thrombosis (DVT) and/or pulmonary embolism (PE) and 100,000 deaths occur as a result.

Venous thromboembolism is therefore estimated to account for $5-10 \%$ of all deaths among hospitalised patients and is classified as the most common cause of preventable death.

At the same time VTE stands as one of the most significant causes of peri-operative mortality. If left without prophylaxis, approximately $20-25 \%$ of general surgical patients will develop DVT/PE and more than $2 \%$ will suffer significant complications from it $(1,2)$.

One of the most obscure aspects of venous thrombosis risk is advancing age. The incidence of venous thromboembolism increases incrementally with age, reaching $>21 \%$ over the age of 65 versus $<2 \%$ for those younger than 45 $(2-5)$.

What is more, this population presents more frequently with $\mathrm{PE}$ on a background of DVT and also has increased mortality attributed to the disease compared to younger patients.

In the surgical setting especially, VTE occurs in $65 \%$ of patients over 70 years without prophylaxis and $16 \%$ of patients over 80 years die early after the diagnosis of VTE in comparison with $2 \%$ before 40 years $(2,6,7)$.

It is therefore worrisome that this risk often remains unrecognised and elderly patients rarely receive appropriate prophylaxis. With the number of aging individuals undergoing major abdominal surgery raising exponentially, this represents a significant healthcare issue.

In this review, we focus on elderly general surgical patients. We summarise the pathophysiology and risk factors that predispose this group to DVT/PE along with the current guidelines for thromboprophylaxis and consider the controversies and questions that require further investigation.

\section{Epidemiology and Risk Factors}

Age itself has been shown to be an independent risk factor for DVT/PE, likely secondary to pathophysiological changes resulting in a hypercoagulable state. Chronic inflammation, age-related changes in the micro-circulation, cellular response to drugs and the presence of cell-derived micro-particles that trigger the coagulation cascade increase susceptibility to deep vein thrombosis (8-10).

In addition to that, elderly patients often have reduced mobility and venous stasis as a result. They also suffer from co-morbidities known to promote VTE (peripheral vascular 
disease, COPD, ischaemic heart disease and heart failure, malignancy, fractures) (11-13).

In combination with the significant tissue trauma associated with surgery, all components of Virchow's classic thrombotic triad are present (Table 1).

Unfortunately, the real risk of VTE in this population remains unrecognized by many clinicians. When combined with the fear that thromboprophylaxis medication will lead to significant bleeding, older patients are often left un- or under-protected from thromboembolic disease while in hospital.

Studies of elderly populations in hospitals both in Europe and the US have revealed that compliance to VTE prophylaxis can be as low as $<50 \%(14-18)$.

The groups studied included medical as well as surgical inpatients to show that risk of VTE in the elderly is both underestimated and undertreated with detrimental effects to their well-being.

\section{Risk Assessment Models}

Traditionally, the assessment of VTE risk encompasses patient and procedure related factors. The type, site, length, urgency and underlying pathology of the operation are combined with individual patient susceptibility to create stratification models and allocation to low-, moderate- and high-risk categories.

Unfortunately, there is no singular algorithm for calculating individual patient risk and correlating these results with expected morbidity /mortality from VTE.

Various models for risk stratification have been proposed in literature, but there is significant variance in their development, and heterogeneity between the published score systems does not allow for direct conclusions.

By far the most widely used is the Caprini score, which stratifies patients in very low, low, moderate and high risk categories after adding points from various factors (19). (Table 2)

It has been externally validated for surgical patients including the critically unwell (20-22).

The estimated baseline risks of VTE are $0.5 \%, 1.5 \%, 3.0 \%$, and $6.0 \%$ in patients at very
Table 1. Risk factors for Venous Thromboembolism

\begin{tabular}{ll}
\hline Age & Factor V Leiden \\
\hline Major surgery & Protein C/S deficiency \\
\hline Fractures & Elevated homocysteine \\
\hline Malignancy & Other inherited thrombotic disorders \\
\hline Reduced mobility & Chemotherapy \\
\hline Oral contraceptives & \\
\hline Hormone replacement & \\
\hline Trauma & \\
\hline Haematological disorders & \\
\hline Obesity & \\
\hline Central venous access & \\
\hline Ischaemic heart disease & \\
\hline COPD & \\
\hline
\end{tabular}

low, low, moderate, and high risk for VTE, respectively (20).

The Rogers score is another model developed for surgical patients using data from 183,069 individuals who underwent a variety of procedures (23).

However, it has not been externally validated and has not seen widespread use.

Other scores such as the Khorana score are developed for specific target populations (eg cancer patients) and therefore their use is limited for the general population cohort.

\section{Methods of Prophylaxis}

\section{A. Mechanical Prophylaxis}

It is obvious that early mobilisation with return to pre-operative physical activities plays a significant role in preventing venous stasis and subsequently venous thromboembolism. Therefore, elderly patients require physiotherapy support to return to at least their normal ambulation status as soon as possible.

Mechanical prophylaxis aims to prevent VTE by hindering venous stasis in the lower limbs and minimizing oedema in the extremities.

It represents an extremely attractive option for the elderly population belonging to the high bleeding risk category and there is strong evidence supporting its use.

The most common method of mechanical 
Table 2. Caprini Risk Assessment Score

\begin{tabular}{|c|c|c|c|}
\hline 1 Point & 2 Points & 3 Points & 5 Points \\
\hline $41-61$ yrs & $61-74$ yrs & $>75$ yrs & Stroke $(, 1 \mathrm{mo})$ \\
\hline Minor Surgery & Arthroscopic Surgery & VTE & Elective arthroplasty \\
\hline $\mathrm{BMI}>25$ & Major open surgery (>45 m) & Family hx of VTE & Hip, pelvis, or leg fracture \\
\hline Swollen legs & Laparoscopic surgery ( . $45 \mathrm{~min}$ ) & Factor V Leiden & Acute spinal cord injury $(, 1 \mathrm{mo})$ \\
\hline Varicose Veins & Malignancy & Prothrombin $20210 \mathrm{~A}$ & \\
\hline Pregnancy/Postpartum & Confined to bed $>72 \mathrm{hrs}$ & Lupus anticoagulant & \\
\hline Unexplained/recurrent abortion & Immobilising plaster cast & Anticardiolipin antibodies & \\
\hline $\begin{array}{l}\text { Oral contraceptives/ } \\
\text { Hormone replacement }\end{array}$ & Central venous access & Elevated serum homocysteine & \\
\hline Sepsis & & $\begin{array}{l}\text { Heparin-induced } \\
\text { thrombocytopenia }\end{array}$ & \\
\hline Serious lung disease & & $\begin{array}{l}\text { Other congenital or acquired } \\
\text { thrombophilia }\end{array}$ & \\
\hline \multicolumn{4}{|l|}{ Abnormal pulmonary function } \\
\hline \multicolumn{4}{|l|}{ Acute Ml } \\
\hline \multicolumn{4}{|l|}{$\mathrm{CHF}<1 / 12$} \\
\hline \multicolumn{4}{|l|}{ Inflammatory bowel disease } \\
\hline Medical patient on bed rest & & & \\
\hline
\end{tabular}

prophylaxis is elastic compression stockings. They increase blood flow in the deep veins of the legs and their efficacy has been proven in multiple studies from orthopaedic and surgical patients, with reduction in the odds of DVT from $60-72 \%$ combined with pharmacological means alone.They can be worn at home and they are very cost-effective. However, they need to be fitted to each patient to avoid constriction of the blood circulation and a subsequent tourniquet effect. Skin changes with necrosis, ulceration, blisters and breaks are unfortunately common in the elderly patients and rare complications such as compartment syndrome and common peroneal nerve palsy must be recognised early (24-25).

Intermittent pneumatic compression stockings utilize air to help promote venous flow in the lower limbs. Apart from the purely mechanical component, their action mechanisms include stimulation of endogenous fibrinolytic mechanisms, reduction in the levels of plasminogen activator inhibitor and increase in the activity of tissue plasminogen activator. The reduction in the odds of distal and proximal DVT has been shown to be around $60 \%$ but results failed to demonstrate or to exclude an effect on PE.

There are many different devices available as well as configuration parameters that have been independently studied to assess the optimal pattern for VTE prophylaxis. IPCs are commonly used for patients on the operating table during long operations combined with ES, and frequently represent the only option in obese patients who cannot be fitted with ESs. The drawback is that they are quite bulky and not portable, so they are almost exclusively used in a hospital setting. Even then compliance can be quite poor. Again, skin ulcers and tears need to be avoided by optimal fitting (25-28).

Both methods have been shown to be more effective when combined with pharmacological prophylaxis in the prevention of VTE than either compression or medication alone (25).

\section{B. Pharmacological Prophylaxis}

A variety of pharmacologic agents have been used for pharmacological prophylaxis. Different types of medication include the heparins, Vitamin K inhibitors, antiplatelets and the newer anticoagulants. 


\section{Unfractionated and Low-molecular weight heparins, Fondaparinux}

Multiple studies have validated the benefit of Unfractionated and Low Molecular Weight Heparin (UH, LMWH) and recently fondaparinux.

Low-dose UFH (5000 U subcutaneously 2-3 times daily starting $2 \mathrm{~h}$ before the procedure) and LMWH are both effective at reducing the occurrence of DVT in general surgery patients. According to meta-analyses and large clinical trials, low-dose UFH reduces the incidence of DVT from about $25 \%$ to $8 \%$, and the incidence of clinically overt and fatal PE by $50 \%$ and $90 \%$, respectively (25).

In another meta-analysis, LDUH was associated with an $18 \%$ reduction in the odds of death from any cause, $47 \%$ reduction in the odds of fatal $\mathrm{PE}$, and $41 \%$ reduction in the odds of nonfatal PE, along with a $57 \%$ increase in the odds of nonfatal major bleeding (25).

Compared with no prophylaxis, LMWH reduces the risk of clinical $\mathrm{PE}$ and clinical VTE by $70 \%$. In addition, LMWH is associated with a possible reduction in the risk of death from any cause. Its use can lead to an approximate doubling of the risks of major bleeding and wound hematoma (25).

Large trials comparing low dose UFH with LMWH in general surgical patients and metaanalysis have suggested that the 2 agents are equally effective.

In meta-analyses the risk for VTE was up to $30 \%$ lower in the LMWH groups. However, this difference was not apparent in blinded, placebo trials and there was no proof of beneficial effect of LMWHvs Unfractionated Heparin on clinical $\mathrm{PE}$, death from any cause, major bleeding, and wound hematoma, although some studies have shown decreased bleeding risk and a safer profile with LMWHs. Mismetti P, Laporte S, Darmon JY, Buchmuller A, Decousus H. Metaanalysis of low molecular weight heparin in the prevention of venous thromboembolism in general surgery. Br J Surg. 2001; (25, 29-31)

LMWHs however have significant advantages compared to Unfractioned Heparin. They can be administered as a once daily dose, they have predictable pharmacokinetics and are less likely to cause heparin-induced thrombocytopenia. They are therefore the agent of choice in patients with normal renal function and no contraindication to blood thinning medication.

Fondaparinux, a synthetic pentasaccharide, has been approved for prophylaxis of DVT. Heparin-induced thrombocytopenia has not been reported with fondaparinux as it does not interact with platelet function and aggregation, and has a predictable response. Monitoring of PT/PTT is also not required. It has an equal or better effectiveness than currently available agents, no need for laboratory monitoring, and once daily administration.

Studies have shown a potentially higher bleeding risk but there were no fatal events or re-bleeding that required re-operation $(25,32)$.

\section{Aspirin}

A meta-analysis in 1994 showed that perioperative acetylsalicylic acid therapy reduces incidence of DVT and PE by $37 \%$ and $71 \%$ respectively for general surgical patients. However, most of the trials included in this meta-analysis used high dose aspirin, and no trials of low dose aspirin regime exist for general surgery (33).

At the moment aspirin is not indicated as a method of thromboprophylaxis, and its use is reserved for those patients in whom other medications are contra-indicated (25).

\section{Warfarin}

Although data are limited for the general surgical cohort, warfarin given postoperatively is likely tobe an effective form of prophylaxis although it is reserved as treatment for patients who have already suffered a thromboembolic event. Serious issues such as delayed onset of action,need for INR monitoring, complex drug and food interactions and a significantly raised risk of bleeding render it an unappealing choice for prevention alone.

\section{Newer Anticoagulants}

The newer anticoagulants, among which rivaroxaban, dabigatran and apixaban, have been approved for treatment of thrombo- 
embolism regardless of background, and as pharmacological prevention in orthopaedic surgery (25).

No trials exist for general surgical inpatients. However, their advantages, especially daily oral administration, could present an alternative to daily LMWH for cohorts of surgical patients requiring prolonged out of hospital prophylaxis $(25,33)$.

\section{Renal Disease}

Most patients over the age of 70 have a degree of chronic renal insufficiency. Impaired renal function and age have both been proven to be a risk factor for bleeding (Spencer 2008, Lacut 2008), mainly due to changes in drug pharmacokinetics, drug interactions from polypharmacy and an increased risk of falls.

Serum creatinine is an inaccurate indicator of the actual kidney function as its production is decreased with the loss of muscle mass that is common in the elderly. Therefore, calculation of Creatine Clearance $(\mathrm{CrCl})$ with equations such as Cockroft-Gault or MDRD is very important (14).

The anticoagulant of choice in the presence of severe renal impairment remains UFH (34). It has a short half-life of 1-2 hrs, it can be easily reversed with protamine sulphate and its clearance does not depend on renal excretion.

Of the LMWHs, there is evidence that as molecular weight increases, the excretion happens mostly via the reticuloendothelial system (14).

Tinzaparin has been proven to be safe in several studies, independently of renal function. The same stands for Dalteparinin prophylactic doses. Many studies prove its efficacy and safety at the widely used dose of 5.000U OD that does not require weight or $\mathrm{CrCl}$ adjustment (25,34-37).

Enoxaparin studies suggest that dose reduction needs to be considered in $\mathrm{CrCl}<30$ while Fondaparinux clearance is directly related to kidney function and dose adjustments are mandatory depending on the degree of renal failure (14).

Measurement of anti-Xa is the only accurate way to assess pharmacokinetics of LMWHs. However it is not routinely performed in clinical practice and it been shown that in the low doses used fro prophylaxis, the levels of anti-Xa are actually difficult to correlate with bleeding risk $(16,38)$.

\section{Duration of prophylaxis}

Unfortunately, there are only few studies addressing the optimal duration of VTE prophylaxis in the surgical population. From observational/retrospective studies, it has been shown that the risk of thromboembolic events remains high for at least 30 days postoperatively and even up to 3 months after discharge. The ratio can be even 10-50 times higher compared to controls and a retrospective review of medical records for newly discharged surgical patients revealed that more patients presented to hospital with signs and symptoms of VTE in the first 3/12 after their discharge compared to the number of inpatients diagnosed $(39,40)$. In another similar study the mean time to DVT was approximately 65 days after discharge (25).

Currently, there are few guidelines on continued prophylaxis for general surgical patients. Most authors advocate use of mechanical compression methods and blood thinning medication for up to 10 days after high-risk procedures, or until the patients regain their pre-operative mobility. When there is extensive abdominal/pelvic surgery on a background of malignancy, this time is extended to at least 30 days post-op.

Among the high-risk group of those patients undergoing abdominal surgery for cancer, there is evidence that compared with limited-duration prophylaxis (1 week), extended-duration prophylaxis (4 weeks) with LMWH provides additional protection from nonfatal VTE, without an important increase in the risk of nonfatal major bleeding complications $(25,41)$.

In other reviews, the incidence of overall VTE after major abdominal or pelvic surgery was $14.3 \%$ in the control vs $6.1 \%$ in the patients receiving out-of-hospital LMWH. Prolonged thromboprophylaxis with LMWH was also 
associated with a statistically significant reduction of even the incidence of symptomatic VTE from $1.7 \%$ to $0.2 \%$ in patients receiving prolonged thromboprophylaxis. There was no significant change in the risk of bleeding (42-44).

It can therefore be inferred that extended prophylaxis is beneficial for surgical patients with high risk for VTE and especially those suffering from malignancy.

\section{Contraindications to Prophylaxis}

The absolute contraindications for drug thromboprophylaxis are those already known for the general adult population.Untreated haemophilia and other haemorrhagic disorders, active bleeding or high bleeding risk (peptic ulcer, recent cerebral haemorrhage, severe hypertension, severe liver disease), thrombocytopenia with platelets $<60 \times 109 / \mathrm{L}$, a history of heparin-induced thrombocytopenia, and hypersensitivity to heparin are all contraindications to treatment.

Age itself has been proven to be a significant predisposing factor for bleeding and bleeding-related complications for patients receiving oral anticoagulants $(7,10,14)$.

While the 3-month risk of major bleeding usually ranges from $2 \%$ to $3 \%$ among patients receiving oral anticoagulants, this risk doubles inpatients aged 65 years. The risk of intracerebral bleeding also doubles in patients aged 80 years or above.

The increased bleeding risk in the elderly can be explained by several factors: a lower metabolic clearance of vitamin Kantagonists, multiple comorbidities, polypharmacy, pathological changes in cerebral vessels and an increased risk for falls.

Evidence suggests that bleeding from antithrombotic agents is a strong predictor of mortality and reduces the overall benefits of VTE prophylaxis in hospitalized patients (14, 45-48).

Guidelines combine the thromboembolic and bleeding risk of patients to create suggestions about optimal VTE prophylaxis with minimal side effects (Table 3).

\section{Conclusions}

There is no doubt that elderly surgical patients have a high risk of VTE and subsequent death from $\mathrm{PE}$, attributed to the aging process itself but also their multiple associated comorbidities. However, because of low clinician awareness of this risk or excessive fear that anticoagulation will lead to fatal bleeding, almost half do not receive the appropriate prophylaxis

Table 3. Recommendations for Thromboprophylaxis in Various Risk Groups

\begin{tabular}{|c|c|c|}
\hline \multicolumn{3}{|c|}{ Risk and Consequences of Major Bleeding Complications } \\
\hline Risk of Symptomatic VTE & Average Risk ( $1 \%$ ) & High Risk ( $2 \%$ ) or Severe Consequences \\
\hline Very low $(<0.5 \%)$ & No specific prophylaxis & \\
\hline Low $(1.5 \%)$ & Mechanical prophylaxis, preferably with IPC & \\
\hline Moderate (3.0\%) & $\begin{array}{l}\text { LDUH, LMWH, or mechanical prophylaxis, } \\
\text { preferably with IPC }\end{array}$ & Mechanical prophylaxis, preferably with IPC \\
\hline High $(6.0 \%)$ & $\begin{array}{l}\text { LDUH or LMWH plus mechanical prophylaxis } \\
\text { with ES or IPC }\end{array}$ & $\begin{array}{l}\text { Mechanical prophylaxis, preferably with IPC, until } \\
\text { risk of bleeding diminishes and pharmacologic } \\
\text { prophylaxis can be added }\end{array}$ \\
\hline High-risk cancer surgery & $\begin{array}{l}\text { LDUH or LMWH plus mechanical prophylaxis } \\
\text { with ES or IPC and extended-duration } \\
\text { prophylaxis with LMWH post-discharge }\end{array}$ & $\begin{array}{l}\text { Mechanical prophylaxis, preferably with IPC, until } \\
\text { risk of bleeding diminishes and pharmacologic } \\
\text { prophylaxis can be added }\end{array}$ \\
\hline $\begin{array}{l}\text { High risk, LDUH and LMWH } \\
\text { contraindicated or not available }\end{array}$ & $\begin{array}{l}\text { Fondaparinux or low-dose aspirin }(160 \mathrm{mg}) \text {; } \\
\text { mechanical prophylaxis, preferably with } \\
\text { IPC; or both }\end{array}$ & $\begin{array}{l}\text { Mechanical prophylaxis, preferably with IPC, until } \\
\text { risk of bleeding diminishes and pharmacologic } \\
\text { prophylaxis can be added }\end{array}$ \\
\hline
\end{tabular}

LDUH: Low dose unfractionated heparin, LMWH: Low molecular weight heparin, ES: Embolic stockings, IPC: Intermittent Pneumatic Compression 
required by their calculated risk.

Existing guidelines suggest that LMWHs in combination with mechanical prophylaxis yield the best results in terms of VTE prevention. However, it is the combination of thromboembolic and bleeding risks for each individual that ultimately guides the decision on method of prophylaxis.

Newer pharmacological agents such as fondaparinux and NOACs have been introduced for surgical and orthopaedic patients, but especially the latter need further studies to establish themselves as a standard for prophylaxis in the general surgical population.

Clinicians need to be aware of the existing risk for VTE both when the patient is hospitalized but also after their discharge. It has been proven beyond doubt that VTE risk and subsequent mortality remain high in a cohort of surgical patients for a long time after their initial hospitalisation.

\section{Conflicts of Interest}

No declarations by the authors.

\section{References}

1. Cohen AT, Tapson VF, Bergmann JF, Goldhaber SZ, Kakkar AK, Deslandes B, et al. Venous thromboembolism risk and prophylaxis in the acute hospital care setting (ENDORSE study): a multinational cross-sectional study. Lancet. 2008;371(9610):387-94. doi: 10.1016/ S0140-6736(08)60202-0.

2. Anderson FA Jr, Wheeler HB, Goldberg RJ, Hosmer DW, Patwardhan NA, Jovanovic B, et al. A population-based perspective of the hospital incidence and case-fatality rates of deep vein thrombosis and pulmonary embolism. The Worcester DVT Study. Arch Intern Med. 1991;151(5):933-8.

3. White RH, Zhou H, Romano PS. Incidence of symptomatic venous thromboembolism after different elective or urgent surgical procedures. Thromb Haemost. 2003;90(3):446-55.

4. Geerts WH, Heit JA, Clagett GP, Pineo GF, Colwell CW, Anderson FA $\mathrm{Jr}$, et al. Prevention of venous thromboembolism. Chest. 2001;119 (1 Suppl):132S-175S.

5. Rosendaal FR1, VAN Hylckama Vlieg A, Doggen CJ. Venous thrombosis in the elderly. J Thromb Haemost. 2007;5 Suppl 1:310-7.

6. Couturaud F, Lacut K, Leroyer C, Mottier D. Assessment of the risk and prophylactic treatment of venous thromboembolism in the elderly. Pathophysiol Haemost Thromb. 2003-2004;33(5-6):362-5.

7. Lacut K, Le Gal G, Mottier D. Primary prevention of venous thromboembolism in elderly medical patients. Clin Interv Aging. 2008:3(3): 399-411.

8. Silverstein MD, Heit JA, Mohr DN, Petterson TM, O'Fallon WM, Melton LJ 3rd. Trends in the incidence of deep vein thrombosis and pulmonary embolism: a 25-year population-based study. Arch Intern Med. 1998;158(6):585-93.

9. Stein PD, Hull RD, Kayali F, Ghali WA, Alshab AK, Olson RE. Venous thromboembolism according to age: the impact of an aging population. Arch Intern Med. 2004;164(20):2260-5.

10. Spencer FA, Gore JM, Lessard D, Emery C, Pacifico L, Reed G, et al. Venous thromboembolism in the elderly. A community-based perspective. Thromb Haemost. 2008;100(5):780-8.

11. Rosendaal FR, van HylckamaVlieg A, Doggen CJ. Venous thrombosis in the elderly. J Thromb Haemost. 2007;5 Suppl 1:310-7.

12. Guyatt GH, Norris SL, Schulman S, Hirsh J, Eckman MH, Akl EA, et al. Methodology for the development of antithrombotic therapy and prevention of thrombosis guidelines: Antithrombotic Therapy and Prevention of Thrombosis, 9th ed: American College of Chest Physicians Evidence-Based Clinical Practice Guidelines. Chest. 2012;141(2 Suppl):53S-70S. doi: 10.1378/chest.11-2288.

13. Engbers MJ, van Hylckama Vlieg A, Rosendaal FR. Venous thrombosis in the elderly: incidence, risk factors and risk groups. J Thromb Haemost. 2010;8(10):2105-12. doi: 10.1111/j.15387836.2010.03986.x.

14. Tincani E, Crowther MA, Turrini F, Prisco D. Prevention and treatment of venous thromboembolism in the elderly patient. Clin Interv Aging. 2007;2(2):237-46.

15. Lau BD, Haut ER. Practices to prevent venous thromboembolism: a brief review. BMJ Qual Saf. 2014;23(3):187-95. doi: 10.1136/ bmjqs-2012-001782. Epub 2013 May 24.

16. Robert-Ebadi H, Righini M. Anticoagulation in the Elderly. Pharmaceuticals. 2010;3(12):3543-3569.

17. Piazza G, Seddighzadeh A, Goldhaber SZ. Double trouble for 2,609 hospitalized medical patients who developed deep vein thrombosis: prophylaxis omitted more often and pulmonary embolism more frequent. Chest. 2007;132(2):554-61. Epub 2007 Jun 15.

18. Piazza G, Seddighzadeh A, Goldhaber SZ. Deep-vein thrombosis in the elderly. Clin Appl Thromb Hemost. 2008;14(4):393-8. doi: 10.1177/1076029608317942. Epub 2008 Jul 1.

19. Caprini JA. Thrombosis risk assessment as a guide to quality patient care. Dis Mon. 2005;51(2-3):70-8.

20. Bahl V, Hu HM, Henke PK, Wakefield TW, Campbell DA Jr, Caprini JA. A validation study of a retrospective venous thromboembolism risk scoring method. Ann Surg. 2010;251(2):344-50. doi: 10.1097/SLA.0b013e3181b7fca6.

21. Bilgi K, Muthusamy A, Subair M, Srinivasan S, Kumar A, Ravi R, et al. Assessing the risk for development of Venous Thromboembolism (VTE) in surgical patients using Adapted Caprini scoring system. Int J Surg. 2016;30:68-73. doi: 10.1016/j.ijsu.2016. 04.030. Epub 2016 Apr 22.

22. Obi AT, Pannucci CJ, Nackashi A, Abdullah N, Alvarez R, Bahl V, et al. Validation of the Caprini Venous Thromboembolism Risk Assessment Model in Critically III Surgical Patients. JAMA Surg. 2015;150(10):941-8. doi: 10.1001/jamasurg.2015.1841.

23. Rogers SO Jr, Kilaru RK, Hosokawa P, Henderson WG, Zinner MJ, Khuri SF. Multivariable predictors of postoperative venous thromboembolic events after general and vascular surgery: results from the patient safety in surgery study. J Am Coll Surg. 2007; 204(6): 1211-21.

24. Sachdeva A1, Dalton M, Amaragiri SV, Lees T. Elastic compression stockings for prevention of deep vein thrombosis. Cochrane Database Syst Rev. 2010;(7):CD001484. doi: 10.1002/14651858. CD001484.pub2.

25. Gould MK, Garcia DA, Wren SM, Karanicolas PJ, Arcelus JI, Heit $J A$, et al. Prevention of VTE in nonorthopedic surgical patients: Antithrombotic Therapy and Prevention of Thrombosis, 9th ed: American College of Chest Physicians Evidence-Based Clinical Practice Guidelines. Chest. 2012;141(2 Suppl):e227S-e277S. doi: 10.1378/chest.11-2297.

26. Choi M, Hector M. Management of venous thromboembolism for older adults in long-term care facilities. J Am Acad Nurse Pract. 2012;24(6):335-44. doi: 10.1111/j.1745-7599.2012.00733.x. Epub 2012 May 3.

27. Urbankova J, Quiroz R, Kucher N, Goldhaber SZ. Intermittent pneumatic compression and deep vein thrombosis prevention. A meta-analysis in postoperative patients. Thromb Haemost. 2005; 
94(6):1181-5.

28. Kakkos SK, Caprini JA, Geroulakos G, Nicolaides AN, Stansby G, Reddy DJ, et al. Combined intermittent pneumatic leg compression and pharmacological prophylaxis for prevention of venous thromboembolism. Cochrane Database Syst Rev. 2016;9: CD005258. [Epub ahead of print]

29. Palmer AJ, Schramm W, Kirchhof B, Bergemann R. Low molecular weight heparin and unfractionated heparin for prevention of thrombo-embolism in general surgery: a meta-analysis of randomised clinical trials. Haemostasis. 1997;27(2):65-74.

30. Mismetti P, Laporte S, Darmon JY, Buchmüller A, Decousus H. Meta-analysis of low molecular weight heparin in the prevention of venous thromboembolism in general surgery. Br J Surg. 2001; 88(7):913-30.

31. National Collaborating Centre for Acute Care. Venous Thromboembolism: Reducing the Risk of Venous Thromboembolism (Deep Vein Thrombosis and Pulmonary Embolism) in Patients Admitted to Hospital. London, England: NICE; 2010.

32. Kesieme E, Kesieme C, Jebbin N, Irekpita E, Dongo A. Deep vein thrombosis: a clinical review. J Blood Med. 2011;2:59-69. doi: 10.2147/JBM.S19009. Epub 2011 Apr 29.

33. [No authors listed]. Collaborative overview of randomised trials of antiplatelet therapy--III: Reduction in venous thrombosis and pulmonary embolism by antiplatelet prophylaxis among surgical and medical patients. Antiplatelet Trialists' Collaboration. BMJ. 1994;308(6923):235-46.

33. Cohen AT, Hamilton M, Mitchell SA, Phatak H, Liu X, Bird A, et al. Comparison of the Novel Oral Anticoagulants Apixaban, Dabigatran, Edoxaban, and Rivaroxaban in the Initial and LongTerm Treatment and Prevention of Venous Thromboembolism: Systematic Review and Network Meta-Analysis. PLoS One. 2015;10(12):e0144856. doi: 10.1371/journal.pone.0144856. eCollection 2015.

34. Büller HR, Agnelli G, Hull RD, Hyers TM, Prins MH, Raskob GE. Antithrombotic therapy for venous thromboembolic disease: the Seventh ACCP Conference on Antithrombotic and Thrombolytic Therapy. Chest. 2004;126(3 Suppl):401S-428S.

35. Shprecher AR, Cheng-Lai A, Madsen EM, Cohen HW, Sinnett MJ, Wong ST, et al. Peak antifactorxa activity produced by dalteparintreatement in patients with renal impairment compared with controls. Pharmacotherapy. 2005;25(6):817-22.

36. Kucher N, Leizorovicz A, Vaitkus PT, Cohen AT, Turpie AG, Olsson $C G$, et al. Efficacy and safety of fixed low-dose dalteparin in preventing venous thromboembolism among obese or elderly hospitalized patients: a subgroup analysis of the PREVENT trial. Arch Intern Med. 2005;165(3):341-5.

37. Gouin-Thibault I, Siguret V, Pautas E. A need for evidence-based clinical practice guidelines for the use of heparins in the elderly. Clin Interv Aging. 2010;5:119-21.

38. Robert-Ebadi H, Le Gal G, Righini M. Use of anticoagulants in elderly patients: practical recommendations. Clin Interv Aging. 2009;4:16577. Epub 2009 May 14.

39. Alsubaie H, Leggett C, Lambert P, Park J, Hochman D, Wirtzfeld D, et al. Diagnosis of VTE postdischarge for major abdominal and pelvic oncologic surgery: implications for a change in practice. Can J Surg. 2015;58(5):305-11.

40. Bouras G, Burns EM, Howell AM, Bottle A, Athanasiou T, Darzi A. Risk of Post-Discharge Venous Thromboembolism and Associated Mortality in General Surgery: A Population-Based Cohort Study Using Linked Hospital and Primary Care Data in England. PLoS One. 2015;10(12):e0145759. doi: 10.1371/journal.pone.0145759. eCollection 2015.

41. Bergqvist D, Agnelli G, Cohen AT, Eldor A, Nilsson PE, Le MoigneAmrani A, et al. Duration of prophylaxis against venous thromboembolism with enoxaparin after surgery for cancer. N Engl J Med. 2002;346(13):975-80.

42. Rasmussen MS, Jørgensen LN, Wille-Jørgensen P. Prolonged thromboprophylaxis with low molecular weight heparin for abdominal or pelvic surgery. Cochrane Database Syst Rev. 2009;(1):CD004318. doi: 10.1002/14651858.CD004318.pub2.

43. Bottaro FJ, Elizondo MC, Doti C, Bruetman JE, Perez Moreno PD, Bullorsky EO, et al. Efficacy of extended thrombo-prophylaxis in major abdominal surgery: what does the evidence show? A metaanalysis. Thromb Haemost. 2008;99(6):1104-11. doi: 10.1160/ TH07-12-0759.

44 Fagarasanu A, Alotaibi GS, Hrimiuc R, Lee AY, Wu C. Role of Extended Thromboprophylaxis After Abdominal and Pelvic Surgery in Cancer Patients: A Systematic Review and Meta-Analysis. Ann Surg Oncol. 2016;23(5):1422-30. doi: 10.1245/s10434-016-5127-1. Epub 2016 Feb 17.

45. Di Minno G, Tufano A. Challenges in the prevention of venous thromboembolism in the elderly. J Thromb Haemost. 2004;2(8): 1292-8.

46. Palareti G, Cosmi B. Bleeding with anticoagulation therapy - who is at risk, and how best to identify such patients. Thromb Haemost. 2009;102(2):268-78. doi: 10.1160/TH08-11-0730.

47. Eikelboom JW, Quinlan DJ, O'Donnell M. Major bleeding, mortality, and efficacy of fondaparinux in venous thromboembolism prevention trials. Circulation. 2009;120(20):2006-11. doi: 10.1161/CIRCULATIONAHA.109.872630. Epub 2009 Nov 2.

48. López-Jiménez L, Montero M, González-Fajardo JA, Arcelus JI, Suárez C, Lobo JL, et al. Venous thromboembolism in very elderly patients: findings from a prospective registry (RIETE). Haematologica. 2006;91(8):1046-51. 